\title{
Lithium, sodium and potassium picolyl complexes: syntheses, structures and bonding
}

\author{
Alan R. Kennedy, ${ }^{a}$ Robert E. Mulvey, ${ }^{a}$ Robert I. Urquhart ${ }^{a}$ and Stuart D. Robertson *a \\ Received (in $X X X, X X X)$ Xth $X X X X X X X X X 20 X X$, Accepted Xth $X X X X X X X X X 20 X X$ \\ ${ }_{5}$ DOI: 10.1039/b000000x
}

Synthetically important for introducing a picolyl scaffold into a molecular construction, alkali metallated picoline (methylpyridine) complexes are also interesting in their own right for the diversity of their ligand-metal bonding possibilities. Here the syntheses of seven new such complexes are reported: namely

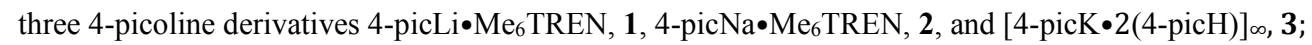

10 and four 2-picoline derivatives, 2-picLi•Me 6 TREN, 4, 2-picLi•PMDETA, 4', 2-picNa•Me 6 TREN, 5, and [2-picK・PMDETA] 2,6 ' [where pic $=\mathrm{NC}_{5} \mathrm{H}_{4}\left(\mathrm{CH}_{2}\right)$; $\mathrm{Me} 6 \mathrm{TREN}=\operatorname{tris}(N, N$-dimethyl-2-

aminoethyl)amine, $\left(\mathrm{Me}_{2} \mathrm{NCH}_{2} \mathrm{CH}_{2}\right)_{3} \mathrm{~N}$; PMDETA $=N, N, N$,,$N$,', $N$ ' '-pentamethyldiethylenetriamine, $\left(\mathrm{Me}_{2} \mathrm{NCH}_{2} \mathrm{CH}_{2}\right)_{2} \mathrm{NMe}$. X-ray crystallographic studies establish that the lighter alkali metal complexes $\mathbf{1}$, $\mathbf{2 , 4}$ ' and $\mathbf{5}$ adopt monomeric structures in contrast to the polymeric and dimeric arrangements adopted by 15 potassium complexes $\mathbf{3}$ and $\mathbf{6}$ ' respectively. All complexes have also been characterized by solution NMR spectroscopy $\left({ }^{1} \mathrm{H},{ }^{13} \mathrm{C}\right.$, and where relevant $\left.{ }^{7} \mathrm{Li}\right)$. This study represents the first example of sodium and potassium picolyl complexes to be isolated and characterized. DOSY (Diffusion-Ordered Spectroscopy) experiments performed on $\mathbf{4}$ and $\mathbf{4}$ ' suggest both compounds retain their monomeric constitutions in $\mathrm{C}_{6} \mathrm{D}_{6}$ solution. Discussion focuses on the influence of the metal and neutral donor molecule on the structures 20 and the nature of the ligand-metal (enamido versus aza-allylic) interactions.

\section{Introduction}

The heterocyclic pyridine ring $\left(\mathrm{NC}_{5} \mathrm{H}_{5}\right)$ is a central feature of a large number of pharmaceutical, ${ }^{1}$ agrochemical ${ }^{2}$ and natural product molecules. ${ }^{3}$ There are of course a plethora of different ${ }_{25}$ methodologies available to the synthetic chemist for the introduction of a pyridine ring into the construction of such a molecule, the particular methodology of choice depending on factors such as the desired substitution on the ring or the ring position which is to be functionalized. One access point which ${ }_{30}$ drew our interest as group 1 metallation chemists was the lithiation and subsequent electrophilic quenching of methylpyridine (picoline). ${ }^{4}$ For example Watson and co-workers recently used this approach starting with lithiated (via $n \mathrm{BuLi}$ ) 2picoline as a first step towards preparing a series of $4 H$ 35 quinolizin-4-ones. ${ }^{5}$ Also, Davis and co-workers laterally metallated 3-cyano-4-picoline with an alkali-metal secondary amide as a key step in their total synthesis of (-)-normalindine. ${ }^{6}$ Intriguingly, the negative charge can be delocalized into the ring from the carbanion and then relocalized onto the ring nitrogen 40 through resonance (the principal resonance forms of the methyldeprotonated anions of 2- and 4-picoline are displayed in figure $1)$.

There have thus far been a variety of studies on the alkali-metal derivatives of $\mathrm{C} \alpha$-substituted 2-picolines, focusing primarily on 45 mono- or di-silylated derivatives. ${ }^{7}$ These complexes can be either

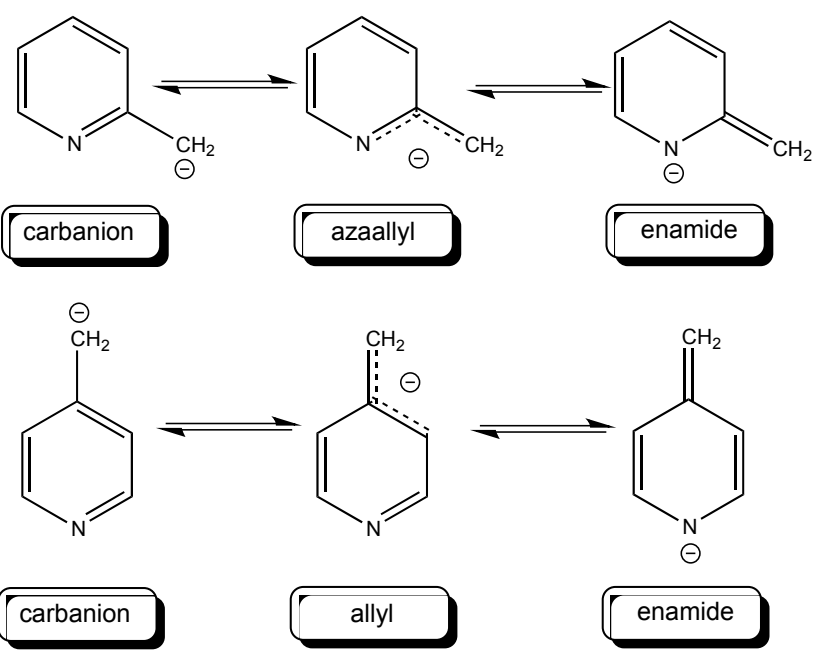

Figure 1 Resonance stabilization of negative charge in 2-picolyl (top) and 4-picolyl (bottom) anions.

monomeric or dimeric, with both aza-allyl and enamido bonding 50 of the anionic picolyl ligand to the metal (figure 2).

Stalke and co-workers have recently studied the bonding of 2picolyllithium via X-ray crystallographic determinations and charge density studies, revealing (diethyl ether/2-picoline solvated) dimeric motifs having both a $\mathrm{Li}-\mathrm{N}$ and $\mathrm{Li}-\mathrm{C}$ (aza- 


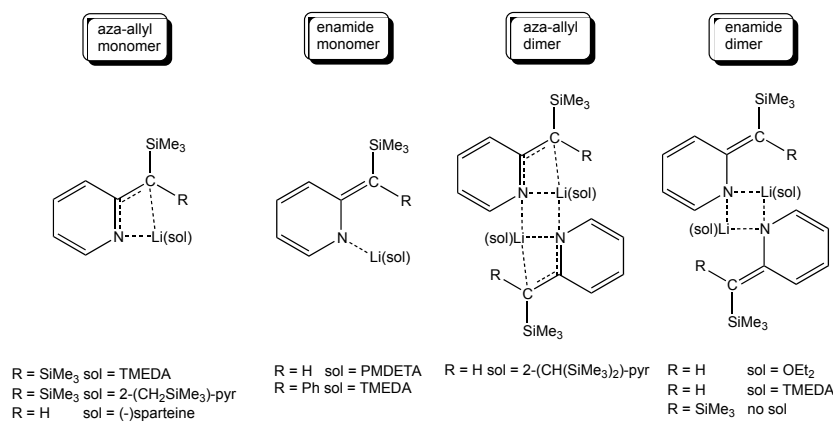

Figure 2 Summary of crystallographically characterized lithium derivatives of $\alpha$-silylated 2 -picolines $($ sol $=$ solvent).

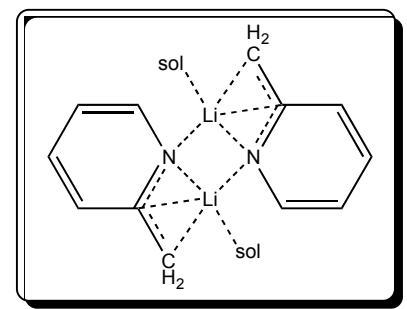

Figure 3 Representation of 2-picolyllithium molecular structures as revealed by Stalke and co-workers. Sol $=\mathrm{OEt}_{2}, 2-\mathrm{picH}$.

allylic) interaction present (figure 3). ${ }^{8}$

Meanwhile, Dhau and Singh have reported the $\alpha$-lithiation of 2picoline and 2,3-lutidine (2,3-dimethylpyridine) using $n \mathrm{BuLi}$ as metalating reagent. ${ }^{9}$ In this study they noted that prior 10 complexation of the heterocycle with Lewis acidic $\mathrm{BF}_{3}$ effects a greater than 2-fold increase in the yield of electrophilically quenched product. This lithiation pattern was in contrast to a previous study of 2-picoline-1-oxide which was lithiated under similar conditions at either the 6 (ring) position or dilithiated at 15 the 6 and $\alpha$ (lateral) positions in approximately equal amounts. ${ }^{10}$ In all cases no metalated intermediates were isolated and identified.

Recently we have been successful in preparing benzyl alkalimetal monomers solvated by tris $(N, N$-dimethyl-220 aminoethyl)amine (Me6TREN), ${ }^{11}$ which has proved to be an effective bonding probe since the hemispheric solvation of the tripodal tetraamine precludes any secondary oligomerizing interactions. On the basis of this precedent we postulated that a similar approach with this ligand would produce monomeric 25 picolyl complexes, stripping out these oligomerizing interactions to give an informative uninterrupted view of the primary metalligand bonding interactions. A particularly attractive feature of Me6TREN in this regard is its exceptional coordinative flexibility, with examples of $\eta^{1},{ }^{12} \eta^{2},{ }^{12} \eta^{3}{ }^{11 d, 13}$ and $\eta^{4}{ }^{11 a, 11 b}$ 30 modes of coordination all reported. We have consequently attempted to prepare $\mathrm{Me}_{6}$ TREN stabilized monomers of 2- and 4picolyl-lithium, -sodium and -potassium and present our findings herein.

\section{Results and discussion}

\section{${ }_{35}$ 4-picolyl complexes}

We commenced by studying the 4-picolyl $\mathrm{M}$ series (where $\mathrm{M}=$
$\mathrm{Li}, \mathrm{Na}$, or $\mathrm{K}$ ) in the presence of our potentially tetradentate Lewis donor. Specifically the lithium salt was prepared in situ (from 4picoline and $n \mathrm{BuLi}$ ) while the heavier congeners were generated 40 via a Lochmann-Schlosser superbase $(n \mathrm{BuLi} / \mathrm{MO} t \mathrm{Bu})$ approach, ${ }^{14}$ filtered, washed with hexane to remove $\mathrm{LiO} t \mathrm{Bu}$ and dried (equation 1).

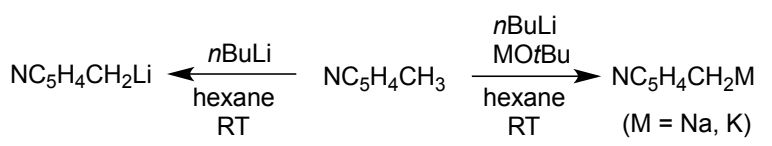

There was no evidence of nucleophilic addition using this 45 method. ${ }^{15}$ This study initially presented more problems than our recent benzyl alkali-metal studies which were carried out with the protonated anion as the bulk solvent (that is toluene and mesitylene). Our preference in this case was not to use bulk 4picoline as the solvent as it may compete with Me6TREN as a 50 solvating ligand for the Lewis acidic alkali-metal. Toluene was also avoided in case this arene was laterally metallated ${ }^{16}$ by our desired products, generating alkali-metal benzyl complexes. We found that in neat diethyl ether or hexane, the 4-picM salts were insoluble in the presence (or absence) of one molar equivalent of ${ }_{55} \mathrm{Me}_{6}$ TREN so THF was added dropwise until a homogeneous solution resulted. In the case of lithium and sodium, crystalline material of complexes 4-picLi॰Me $6 \mathrm{TREN}$ (1) and 4picNa•Me 6 TREN (2) was deposited in moderate yield (29 and 28 $\%$, respectively) at $-30^{\circ} \mathrm{C}$. Molecular structural determinations by ${ }_{60} \mathrm{X}$-ray diffraction studies proved that these complexes were indeed mononuclear. Complex $\mathbf{1}$ is displayed in figure 4, while complex 2 being isostructural is not shown for brevity.

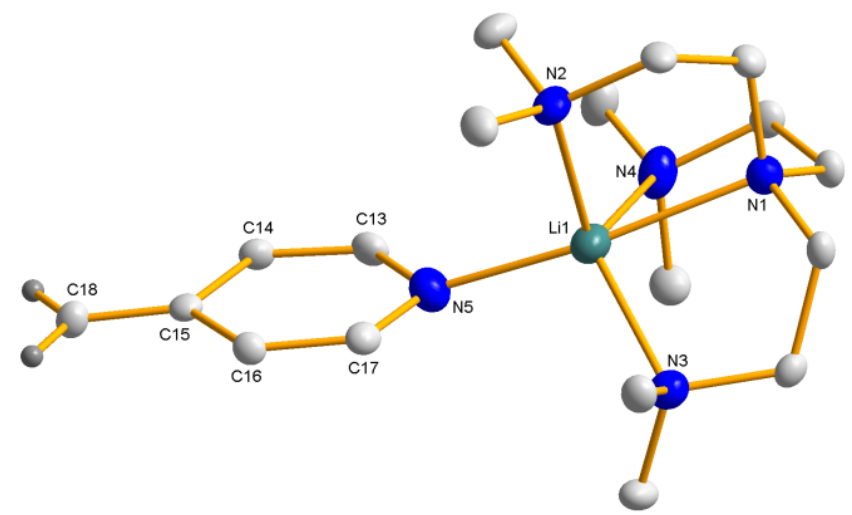

Figure 4 Molecular structure of 4-picLi• $\mathrm{Me}_{6} \mathrm{TREN}$ (1). Ellipsoids are displayed at $50 \%$ probability and all hydrogen atoms (other than those 65 which were freely refined on the deprotonated carbon atom) and noninteracting solvent of crystallization (THF) are omitted for clarity. Selected bond lengths $(\AA)$ and angles $\left({ }^{\circ}\right)$ : Li1-N1, 2.238(4); Li1-N2, 2.172(4); Li1-N3, 2.223(4); Li1-N4, 2.719(4), Li1-N5, 2.063(4); N1-Li1-

N2, 82.1(1); N1-Li1-N3, 81.8(1), N1-Li1-N4, 72.3(1); N1-Li1-N5, 70 169.1(2); N2-Li1-N3, 113.5(2); N2-Li1-N4, 112.6(2); N2-Li1-N5, 99.3(1); N3-Li1-N4, 122.5(2), N3-Li1-N5, 107.2(2); N4-Li1-N5, 97.3(1).

What is instantly clear from the molecular structure of $\mathbf{1}$ is that the picolyl anion is behaving as a secondary amide rather than a 75 carbanion with the lithium only contacting the anionic fragment via its nitrogen atom and not through any of its carbon atoms. Given Stalke's previous dimeric complexes this is in itself not surprising although it is gratifying that we have prepared another 
sensitive monomer solvated and stabilized with $\mathrm{Me}_{6}$ TREN through which we can accurately probe the primary bonding. The Li-Nanion distance [2.063(4) $\AA$ ] is noticeably longer than that in other monomeric lithium secondary amides, such as $5\left(\mathrm{Me}_{3} \mathrm{Si}\right)_{2} \mathrm{NLi} \cdot \mathrm{TMEDA}$ and $\left(\mathrm{Me}_{3} \mathrm{Si}\right)_{2} \mathrm{NLi} \cdot \mathrm{TMEDA}$ which have Li-

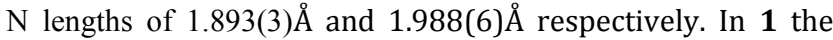
lithium cation lies $0.527(4) \AA$ out of the plane of the sixmembered $\mathrm{C}_{5} \mathrm{~N}$ pyridyl ring [C15-N5-Li1 $\left.=164.6(1)^{\circ}\right]$ and is coordinated by all four nitrogen atoms of $\mathrm{Me}_{6}$ TREN giving an 10 overall distorted trigonal bipyramidal geometry with $\mathrm{N} 1$ and $\mathrm{N} 5$ in the axial positions $\left[\mathrm{N}_{\mathrm{ax}}-\mathrm{Li}-\mathrm{N}_{\mathrm{ax}}=169.1(2)^{\circ} ; \mathrm{N}_{\mathrm{ax}}-\mathrm{Li}-\mathrm{N}_{\mathrm{eq}}=\right.$ 72.3(1)-107.2(2) $\left.{ }^{\circ} ; \quad \mathrm{N}_{\mathrm{eq}}-\mathrm{Li}-\mathrm{N}_{\mathrm{eq}}=112.6(2)-122.5(2)^{\circ}\right]$. Most interesting of the Li- $\mathrm{N}_{\text {donor }}$ distances in $\mathbf{1}$ is that one of them is considerably elongated by almost $0.5 \AA$ compared to the other 15 three [Li-N4, 2.719(4) $\AA$ ] . This weaker bond may be indicative of fluxional $\eta^{3} / \eta^{4}$ coordination in solution. We note here that another Me6TREN solvated monomeric secondary amide, $\left(\mathrm{Me}_{3} \mathrm{Si}\right)_{2} \mathrm{NLi} \bullet \mathrm{Me}_{6} \mathrm{TREN}$, is only coordinated through three of its four Lewis basic heteroatoms in the solid state though the larger 20 bulk of $\left(\mathrm{Me}_{3} \mathrm{Si}\right)_{2} \mathrm{NLi}$ compared to picolylLi is a major contributing factor. The three shorter $\mathrm{Li}-\mathrm{N}_{\mathrm{donor}}$ distances (mean value, $2.211 \AA$ ) in $\mathbf{1}$ are consistent with those seen in $\mathrm{Li}$ $\mathrm{Me}_{6}$ TREN interactions of other complexes. ${ }^{11 \mathrm{a}, 11 \mathrm{~b}}$

Despite several attempts, a high quality structure of $\mathbf{2}$ could not 25 be obtained, though the current low quality structure confirms that the connectivity mirrors that of its lighter lithium congener $\mathbf{1}$. Moving to the potassium congener, despite several attempts we were unable to obtain a pure solid product. In an endeavour to rectify this, the parent picoline 4-picH was itself used to 30 solubilize the hexane suspension of 4-picK and Me 6 TREN as opposed to THF in the case of $\mathbf{1}$ and $\mathbf{2}$ (approx. 20 molar equivalents were required). The resulting crystalline product was revealed to be a 4-picH solvated polymeric structure [4picK-2(4-picH) $]_{\infty}$ (3) which does not contain $\mathrm{Me}_{6}$ TREN as 35 displayed in figure 5 . As can be discerned from figure 5 there are clearly three distinct types of picoline entities present in this structure (labeled A-C). Two of the rings (B and C) bridge between two potassium atoms while the third $(\mathbf{A})$ is a terminal ligand, giving potassium an overall coordination number of five 40 and a distorted square pyramidal coordination sphere, with N2' in the axial position and $\mathrm{N} 1, \mathrm{~N} 2, \mathrm{~N} 3$ and $\mathrm{N}^{\prime}$ in the equatorial positions $\left(\mathrm{N}_{\mathrm{eq}}-\mathrm{K}-\mathrm{N}_{\mathrm{eq}}\right.$ range $=76.49-117.14^{\circ} ; \mathrm{N}_{\mathrm{eq}}-\mathrm{K}-\mathrm{N}_{\mathrm{ax}}$ range $75.09-95.32^{\circ}$ ). However, the presence of a long range $\pi$ interaction between potassium and the $\mathrm{C}=\mathrm{C}$ double bond of a ${ }_{45}$ picolyl ligand $[\mathrm{K} 1-\mathrm{C} 26 "=3.371(2) \AA ̊]$ from an adjacent unit of the polymeric chain serves as a sixth coordination site to give a distorted octahedral geometry (figure 5, bottom) as well as confirming that this picolyl unit is the deprotonated one (vide infra). Of course the distortion from octahedral geometry can be so easily explained by a number of steric and electronic factors, including the mixture of $\pi$ and $\sigma$ bonding, the sterics of the ligands, the fact that some ligands are bridging and others terminal, and the constraints imposed by the presence of fourmembered $\mathrm{K}_{2} \mathrm{~N}_{2}$ cycles.

${ }_{55}$ To determine which of the three distinct picoline molecules present in the structure is the anionic ligand needed to balance the charge of the potassium cation we compared the bond lengths of these rings with those of the picolyl anion in $\mathbf{1}$ (table 1). This

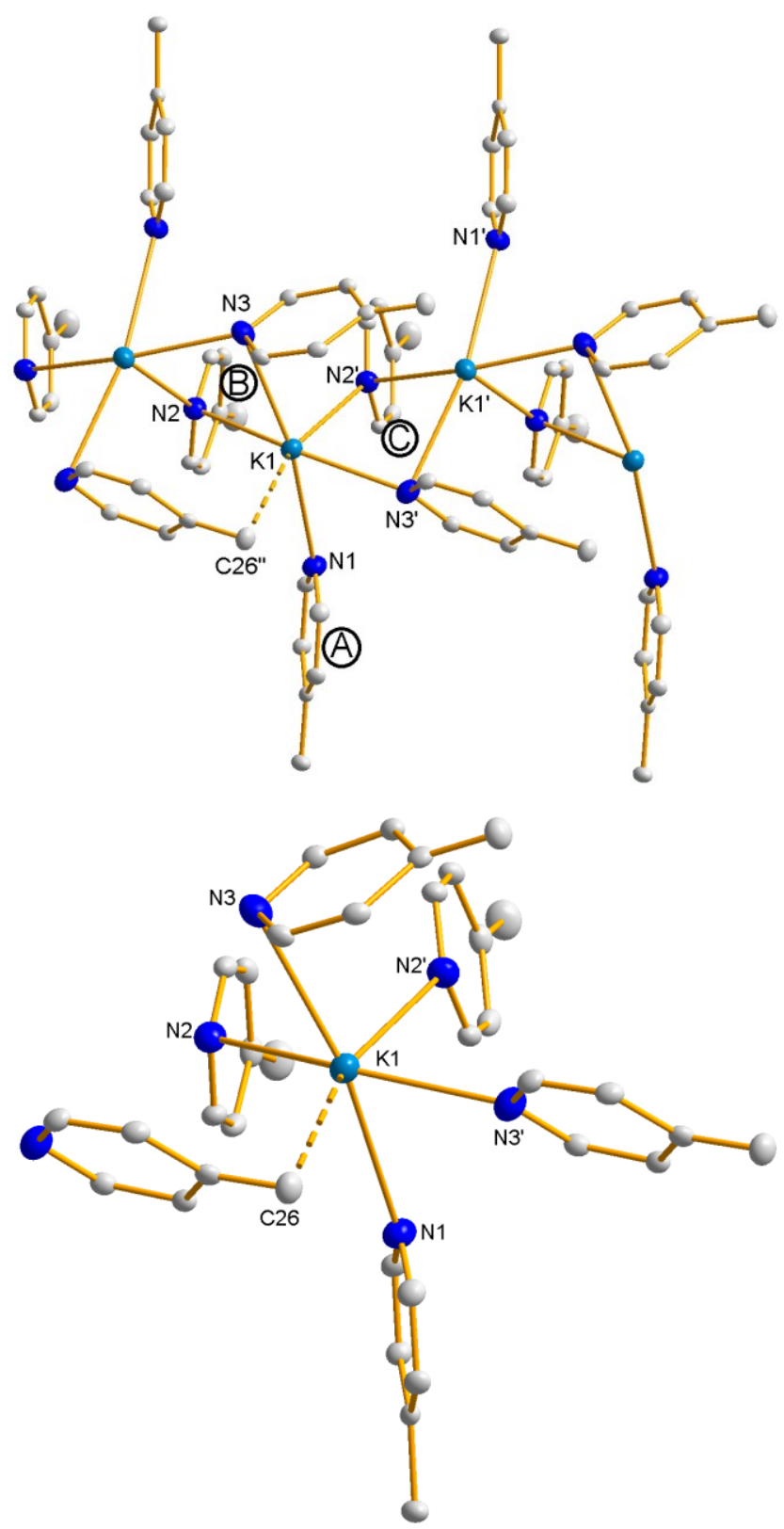

Figure 5 A section of the polymeric chain structure of [4-picK $\bullet 2(4-$ $60 \mathrm{picH}$ ) ] $]_{\infty}(3)$ (top) that propagates parallel to the crystallographic a direction and detail of the coordination geometry of the potassium atom within it (bottom). Ellipsoids are displayed at $50 \%$ probability and all hydrogen atoms are omitted for clarity. Selected bond lengths $(\AA)$ and angles $\left({ }^{\circ}\right)$ : K1-N1, 3.082(1); K1-N2, 3.044(1); K1-N3, 2.950(1); K1-N2', 65 3.009(1); K1,N3', 2.755(1); K1 ‥C26", 3.371(2); N1-K1-N2, 86.72(4); N1-K1-N3, 166.25(4); N1-K1-N2', 84.05(4); N1-K1-N3', 76.49(4); N1K1-C26", 91.90(4); N2-K1-N3, 79.88(4); N2-K1-N2', 75.09(3); N2-K1N3', 154.16(4); N2-K1-C26", 119.60(4); N3-K1-N2', 95.32(4); N3-K1N3', 117.14(4); N3-K1-C26", 92.10(4); N2'-K1-N3', 83.64(4); N2'-K170 C26", 164.61(4); N3'-K1-C26", 80.97(5), K1-N2'-K1', 84.08(3), K1N3'-K1', 90.47(4), where ' $=\mathrm{x}+1 / 2 \cdot-\mathrm{y}+1 / 2, \mathrm{z}$ and ' $=\mathrm{x}-1 / 2,-\mathrm{y}+1 / 2, \mathrm{z}$.

showed that the bond lengths of ring $\mathbf{C}$ are consistent with the loss of aromaticity (elongated $\mathrm{N}-\mathrm{C} \alpha$ and $\mathrm{C} \beta-\mathrm{C} \gamma$ bonds and shortened $\mathrm{C} \alpha-\mathrm{C} \beta$ and $\mathrm{C} \gamma$-C lateral bonds suggesting alternating 75 single and double bonds throughout the ligand). The picolyl anion would appear to be displaying both $\sigma$ and $\pi$ bonding character to the two potassium atoms (K-N-C $\gamma$ angles are 175.61(6) and $89.37(5)^{\circ}$ respectively). The designation of ring $\mathbf{C}$ as the anionic 
(deprotonated) ligand was further supported crystallographically by locating and refining two hydrogen atoms on the lateral carbon atom; these lie in the plane of the aromatic ring confirming the $\mathrm{sp}^{2}$ hybridization of this carbon atom and thus conversion to an 5 anion. The $\pi$ character of the $\mathrm{C} \gamma-\mathrm{C}_{\text {lateral }}$ bond is further confirmed by its participation in an interaction with $\pi$-philic potassium (vide supra).

Table 1 Selected bond parameters for 4-picolyl rings of complexes 1 and 3

\begin{tabular}{|c|c|c|c|c|}
\hline & \multirow[t]{2}{*}{1} & \multicolumn{3}{|c|}{3} \\
\hline & & $\mathbf{A}$ & B & $\mathrm{C}$ \\
\hline & $1.351(3)$ & $1.333(2)$ & $1.333(2)$ & $1.365(2)$ \\
\hline $\mathrm{N}-\mathrm{C} \alpha$ & $1.359(3)$ & $1.337(2)$ & $1.344(2)$ & $1.357(2)$ \\
\hline & $1.364(3)$ & $1.385(2)$ & $1.372(2)$ & $1.358(2)$ \\
\hline$C_{\alpha}-C \beta$ & $1.362(3)$ & $1.383(2)$ & $1.388(2)$ & $1.360(2)$ \\
\hline & $1.444(3)$ & $1.381(2)$ & $1.387(2)$ & $1.443(2)$ \\
\hline$C \beta-C \gamma$ & $1.442(3)$ & $1.390(2)$ & $1.386(2)$ & $1.449(2)$ \\
\hline $\mathrm{C} \gamma-\mathrm{C}_{\text {lateral }}$ & $1.365(3)$ & $1.502(2)$ & $1.506(2)$ & $1.367(3)$ \\
\hline
\end{tabular}

10

Despite various attempts utilising varying solvents, adding excess Me6TREN to a solution of $\mathbf{3}$, or utilizing other polydentate donor molecules we have thus far been unable to prepare a monomeric potassium complex of the 4-picolyl anion.

15 A solution state study of complexes 1-3 proved to be challenging. Unlike our monomeric benzyl complexes, these picolyl complexes were insoluble in standard NMR solvents such as $d_{6-}$ benzene or $d_{12}$-cyclohexane. We thus changed to more polar $d_{8-}$ THF which in the case of $\mathbf{1}$ and $\mathbf{3}$ furnished us with orange/red 20 coloured solutions. Complex $\mathbf{2}$ was only sparingly soluble even in this solvent but it was sufficient to assign the majority of the resonances. These complexes all showed upfield shifts of the aromatic proton resonances compared to those of 4-picH with concomitant downfield shifts of the resonances corresponding to 25 the lateral $\mathrm{CH}_{2}$ arm. Unlike the benzyl series, the resonances for 1-3 were all located in a very similar region, suggesting that there was a similar bonding pattern occurring across the series, consistent with the molecular structures which displayed $\sigma$ bonding of the metal to the nitrogen atom in each case. It must be 30 noted here that the donor ligands ( $\mathrm{Me}_{6} \mathrm{TREN}$ in 1, 2; 4-picH in 3) gave resonances corresponding to these molecules in the free uncoordinated state, and thus it is likely that in solution we are probably witnessing a series of complexes of general formula 4picM•xTHF ( $\mathrm{M}=\mathrm{Li}, \mathrm{Na}, \mathrm{K}$; $\mathrm{x}$ unknown) in these bulk THF 35 solutions. That said these spectra unequivocally confirm the empirical makeup and purity of the bulk crystalline material. ${ }^{13} \mathrm{C}$ NMR spectra are in all cases as expected while the ${ }^{7} \mathrm{Li}$ spectrum of complex $\mathbf{1}$ displays a lone sharp singlet.

\section{2-picolyl complexes}

${ }_{40}$ The same protocol discussed above (equation 1) was repeated using isomeric 2-picoline as the substrate to prepare the unsolvated alkali-metal salts. A molar equivalent of Me6TREN was introduced followed by THF until a homogenous solution was obtained. Crystallization of the final products was found to 45 be easier and higher yielding from diethyl ether solutions rather than hexane solutions. For $\mathrm{M}=\mathrm{Li}\left(2-\mathrm{picLi} \bullet \mathrm{Me}_{6} \mathrm{TREN}, 4\right)$, a crop of red crystals resulted which were not of sufficient quality for Xray diffraction studies.

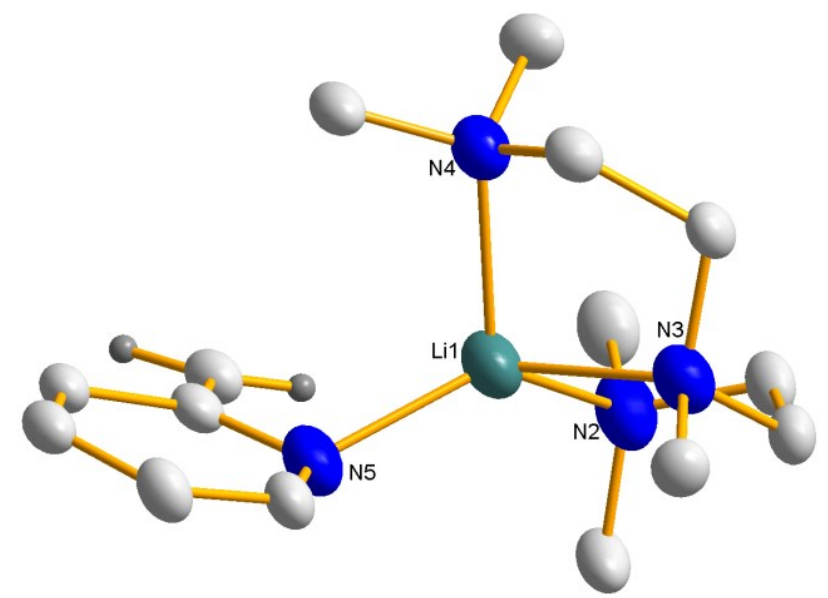

Figure 6 Molecular structure of one of the crystallographically independent molecules of 2-picLi•PMDETA (4'). Ellipsoids are

displayed at $50 \%$ probability and all hydrogen atoms are omitted for clarity. Selected bond lengths $(\AA)$ and angles $\left({ }^{\circ}\right)$ : Li1-N2, 2.139(7); Li1N3, 2.147(7); Li1-N4, 2.139(7); Li1-N5, 2.002(4); N2-Li1-N3, 85.0(2); N2-Li1-N4, 116.8(3); N2-Li1-N5, 129.9(3); N3-Li1-N4, 86.8(3); N3-Li155 N5, 120.9(3); N4-Li1-N5, 107.5(3).

Being unable to obtain a molecular structure of $\mathbf{4}$, we decided to try a different bulky polydentate Lewis donor in the hope that recrystallization would this time yield X-ray quality crystals. This 60 was duly achieved using the moderately less bulky polyamine PMDETA $(N, N, N$ ', $N$ ', $N$ ''-pentamethyldiethylenetriamine). The molecular structure of the resulting complex, 2-picLi•PMDETA (4'), is shown in figure 6 .

In this instance the tridentate donor has sufficient bulk and 65 coordination sites to stabilize a 4-coordinate lithium monomer. This metal is considerably distorted from a tetrahedral geometry due to the two chelate rings which impose N-Li-N bond angles of 85.0(2) and 86.8(3) ${ }^{\circ}$. Li-N $\mathrm{N}_{\text {donor }}$ distances [2.139(7)-2.147(7) $\AA$ ] are marginally shorter than the corresponding bonds in complex 701 reflecting the reduction in coordination number of $\mathrm{Li}$ in $\mathbf{4}^{\prime}$. This narrow Li-N $\mathrm{N}_{\text {donor }}$ range is in contrast to a series of PMDETA solvated monomeric secondary amides studied by Andrews et al. 7c, 17 and in Henderson and Williard's $\left(\mathrm{Me}_{3} \mathrm{Si}\right)_{2} \mathrm{NLi} \cdot \mathrm{PMDETA} 18$ whose reports commented that the 75 bond to the central nitrogen atom is typically elongated compared to that to the two terminal nitrogen atoms (in the range 3.1-6.7\% longer than the average of the two 'terminal' $\mathrm{N}$-Li bonds). This disparity is unlikely to be purely steric in nature as Snaith showed the bulky PMDETA $\bullet \operatorname{LiNPh}(1$-naphthyl) 80 has a much narrower range of Li-NPMDETA bond lengths [2.18(1)$2.22(1) \AA] .{ }^{19}$ Most importantly, the 2-picolyl anion in 4' is behaving as an enamido $\left(\eta^{1}\right)$ ligand, binding to the metal only through its nitrogen atom. To reach this conclusion, we compared metal-anion and picolyl C-C and C-N bond distances with those 85 of Stalke's aza-allyl 2-picLi•2-picH species. ${ }^{8}$ This shows that in our complex, the single bond/double bond character of the N-C-C unit is more pronounced while crucially, our $\mathrm{C}$-Li bond distances are considerably longer at 2.980(7) and 2.796(7) $\AA$ for $\mathrm{C}_{\text {lateral }} \mathrm{Li}$

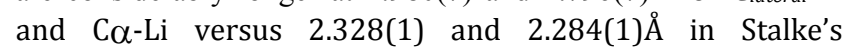
${ }_{90}$ complex. ${ }^{8}$ The $\mathrm{N}-\mathrm{C} \alpha-\mathrm{C}_{\text {lateral }}$ angle is similar in the enamido 
$\left[119.6(3)^{\circ}\right]$ and aza-allyl complexes [119.77으 although this is perhaps to be expected since the central $\mathrm{C}_{\alpha}$ is formally three coordinate and planar in either case. The metal in 4' lies much further out of the plane of the $\mathrm{C}_{5} \mathrm{~N}$ ring [1.126(6) $\left.\mathrm{A}\right]$ than in 5 complex 1 [0.526(4)Å] reflecting the closer proximity of the picolyl ring substituent to the Li-PMDETA moiety.

Table 2 Selected bond distances for 2-picolyl rings of complexes 4', [2picLi•2-picH] $]_{2}$ and 6'.

\begin{tabular}{|c|c|c|c|}
\hline & & & \\
\hline
\end{tabular}

${ }^{\mathrm{a}}$ values in parenthesis represent those to the second $\mathrm{K}$ atom in this 10 cyclodimeric species (denoted K1' in figure 8).

The reaction to prepare the $\mathrm{Me}_{6} \mathrm{TREN}$ solvated sodium derivative of 2-picoline, 2-picNa・Me ${ }_{6}$ TREN (5) was carried out in an identical manner to that which prepared 2, furnishing red crystals ${ }_{15}$ isolated in a $54 \%$ yield. Determination of the molecular structure by X-ray diffraction studies showed the complex to be the desired monomer (figure 7), with what appears to be $\eta^{1}$ coordination of the picolyl ligand (through N5) to the metal. However, the molecular structure was not of sufficient quality to unequivocally 20 confirm this due to disorder in the picolyl anion. Consequently we had to rely on solution NMR spectroscopic data to determine the bonding mode (vide infra).

Finally in this series we attempted to prepare the $\mathrm{Me}_{6} \mathrm{TREN}$ solvated potassium congener $\mathbf{6}$. Unfortunately we were unable to 25 obtain a tangible pure product. We did, however, obtain a crystalline product $[2 \text {-picK } \cdot \text { PMDETA }]_{2}\left(\mathbf{6}^{\prime}\right)$ upon changing the donor ligand to PMDETA. Its molecular structure (figure 8) revealed a centrosymmetric dimeric constitution with a central strictly planar $\mathrm{K}_{2} \mathrm{~N}_{2}$ ring and a molecule of PMDETA tridentately 30 capping each potassium atom.

The bond lengths in the picolyl anion of ' $'$ ' suggest that there is perhaps a degree of $\eta^{3}$ aza-allylic type bonding to potassium. Specifically the N-C $\alpha$ bond $[1.395(3) \AA]$ is similar to that of Stalke's $\eta^{3}$ aza-allyl lithium complex (vide supra) while the $\mathrm{C} \alpha$ ${ }_{35}$ Clateral bond $[1.371(3) \AA]$ is intermediate between the values witnessed for Stalke's complex [1.382(1) $\AA$ ] and our own $\eta^{1}$ enamide complex $4^{\prime}[1.356(6) \AA ̊]$. The absolute values for the K-

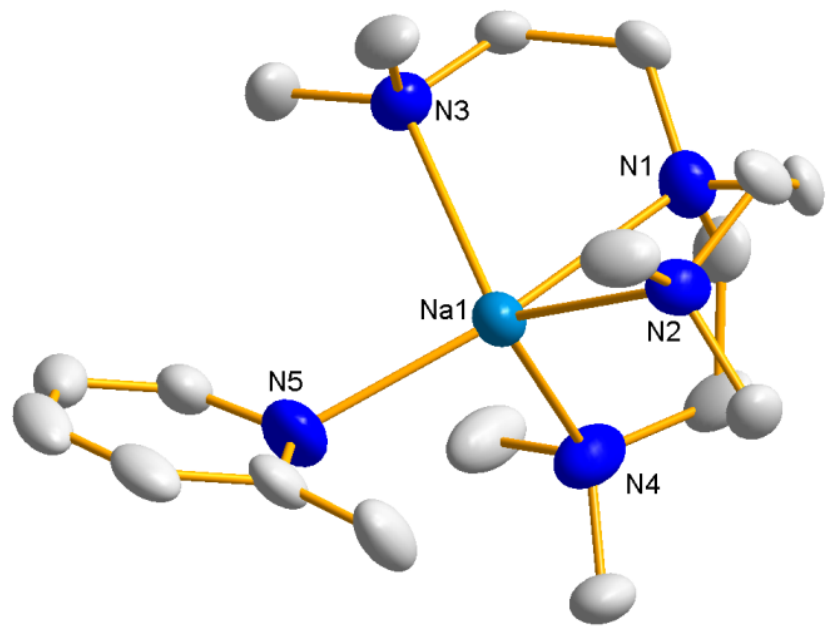

Figure 7 Molecular structure of 2-picNa・Me ${ }_{6}$ TREN (5). Ellipsoids are displayed at $50 \%$ probability and all hydrogen atoms and minor 40 disordered component of 2-picolyl anion are omitted for clarity.

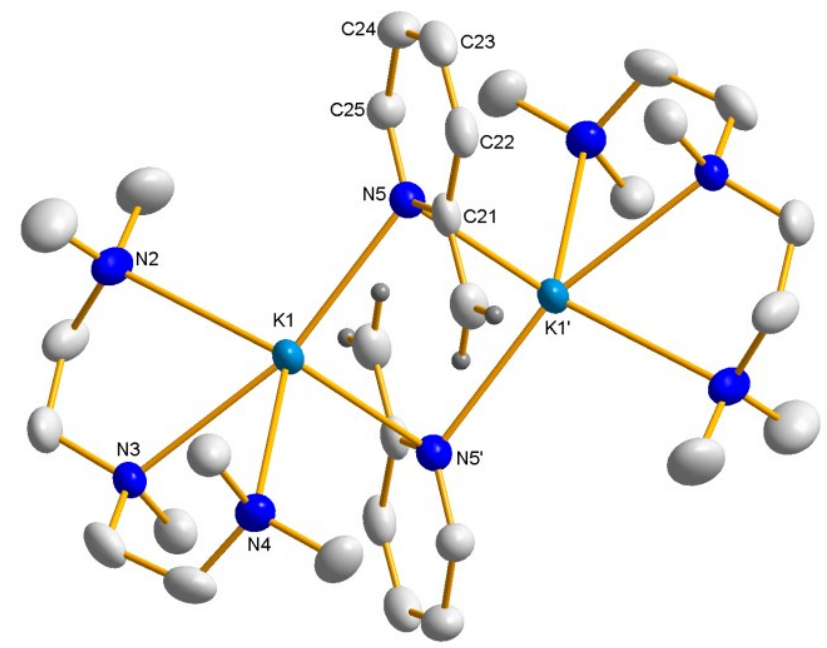

Figure 8 Molecular structure of [2-picK•PMDETA $]_{2}\left(\mathbf{6}^{\prime}\right)$. Ellipsoids are displayed at $50 \%$ probability and all hydrogen atoms (except those of the metalated $\mathrm{CH}_{2}$ group) and minor disordered component at one end of

45 PMDETA molecule are omitted for clarity. Symmetry operation to generate equivalent atoms labeled ': $1-\mathrm{x},-\mathrm{y}, 1-\mathrm{z}$. Selected bond lengths $(\AA)$ and angles $\left({ }^{\circ}\right)$ : K1-N2, 2.915(2); K1-N3, 2.857(2); K1-N4, 2.899(2); K1-N5, 2.786(1); K1-N5', 2.815(1); N2-K1-N3, 63.31(4); N2-K1-N4, 113.02(5); N2-K1-N5, 101.80(4); N2-K1-N5', 132.00(5); N3-K1-N4, $50 \quad$ 62.25(5); N3-K1-N5, 165.03(4); N3-K1-N5', 100.88(5); N4-K1-N5, 127.30(5); N4-K1-N5', 94.04(5); N5-K1-N5', 90.36(5); K1-N5-K1', $89.64(5)$

$\mathrm{N}$ or K-C bonds are not particularly indicative given that this structure represents the first crystallographically characterized ${ }_{55}$ complex of 2-picolyl potassium. However, the ratio of such bond lengths perhaps reveal the true nature of these interactions. In complex 4' (enamide) the M-Clateral/M-N ratio is 1.48 while that of [2-picLi•2-picH $]_{2}$ (aza-allyl) is 1.15 . The corresponding values for 6' are 1.19 (K1) and 1.16 (K1') suggesting aza-allylic 60 character. However, this disparity could of course be an unavoidable artefact of dimerization, since the former complex is a monomer and the 'aza-allylic' complexes are dimers.

The solution chemistry of new complexes $4,4,, 5$ and 6 ' were then probed in $\mathrm{C}_{6} \mathrm{D}_{6}$ solution by ${ }^{1} \mathrm{H}$ NMR spectroscopy. Results ${ }_{65}$ are summarized in table 3. Corresponding data for $\mathrm{Et}_{2} \mathrm{O}$ and 2- 
Table 3 Selected ${ }^{1} \mathrm{H}(400 \mathrm{MHz})$ and ${ }^{13} \mathrm{C}(100 \mathrm{MHz})$ NMR data recorded in $\mathrm{C}_{6} \mathrm{D}_{6}$ solution.

\begin{tabular}{|c|c|c|c|c|c|c|}
\hline 3 & \multicolumn{4}{|c|}{$\mathrm{Li}$} & $\mathrm{Na}$ & \multirow[b]{2}{*}{ PMDETA } \\
\hline & \multicolumn{2}{|c|}{ - $\mathrm{Me}_{6} \mathrm{TREN} \cdot \bullet \mathrm{PMDETA}$} & \multirow[t]{2}{*}{ - $\mathrm{Et}_{2} \mathrm{O}$} & \multirow{2}{*}{-2-picH } & \multirow{2}{*}{$\begin{array}{c}-\mathrm{Me}_{6} \mathrm{TREN} \\
(\mathbf{5})\end{array}$} & \\
\hline & (4) & $\left(4^{\prime}\right)$ & & & & $\left(6^{\prime}\right)$ \\
\hline H2 & 6.37 & 6.36 & 5.53 & 6.31 & 6.37 & 6.14 \\
\hline H3 & 6.59 & 6.61 & 5.92 & 6.52 & 6.69 & 6.52 \\
\hline H4 & 5.42 & 5.41 & 4.67 & 5.47 & 5.49 & 5.35 \\
\hline H5 & 7.16 & 7.08 & 6.76 & 7.52 & 7.40 & 7.36 \\
\hline H6 & $3.46 / 2.83$ & $3.44 / 2.79$ & $2.55 / 2.41$ & 3.39 & $3.28 / 2.96$ & $3.17 / 2.88$ \\
\hline C4 & 95.3 & 95.2 & 95.8 & 100.2 & 95.5 & 96.0 \\
\hline
\end{tabular}

picoline solvated derivatives of $\mathbf{4}$ are included for comparison 5 purposes. What is readily noticeable in the data for the lithium complexes is that the Me6TREN (4), PMDETA (4') and 2picoline solvates all display similar resonances while the resonances of the etherate complex are considerably more shielded. We surmised that this was perhaps an aggregation 10 effect, with the 2-picoline solvate deaggregating to a monomer in solution and thus giving a similar spectrum to those of monomeric 4 and 4'. However, DOSY NMR experiments ${ }^{4 a,} 20$ suggest that these complexes maintain their solid state structural integrity in solution giving experimentally determined 15 approximate molecular weights of 317,267 and $387 \mathrm{~g} \mathrm{~mol}^{-1}$ respectively [c.f. theoretical values of 329,272 and 384 for 4 (monomer), 4' (monomer) and 2-picLi•2-picH (dimer)] representing errors of only $3.65,1.84$ and $0.78 \%$ respectively (see Figure 9, Graph 1 and Table 4 for results of study for 20 complex 4; other results are available in supporting information) and intimating that the NMR anomalies are not a consequence of solution aggregation. ${ }^{13} \mathrm{C}$ NMR data were also compared (table 3 ) in an attempt to determine if the lithium picolyl interaction (that is $\eta^{1}$ versus $\eta^{3}$ ) in solution was responsible. Konishi and ${ }_{25}$ Takahashi have previously suggested that the $\mathrm{C} 4$ resonance (that is the carbon transannular to the substituted $\mathrm{C} \alpha$ ) is most indicative of localization of the negative charge on nitrogen $\left(\eta^{1}\right),{ }^{21}$ however these data (table 3 ) would actually suggest that complexes 4 (95.3 ppm), 4' (95.2 ppm) and [2-picLi•Et $\left.\mathrm{O}_{2}\right]_{2}(95.8$ $30 \mathrm{ppm})$ have similar charge localization and that complex [2picLi•2-picH]2 $(100.2 \mathrm{ppm})$ has greater charge delocalization through the $\mathrm{N}-\mathrm{C}-\mathrm{CH}_{2}$ subunit. The disparity of the ${ }^{1} \mathrm{H}$ NMR resonances of $\left[2-\mathrm{picLi} \mathrm{Et}_{2} \mathrm{O}\right]_{2}$ when compared to 4, 4' and [2picLi•2-picH $]_{2}$ may therefore simply be a consequence of the 35 identity of the Lewis donating heteroatom (oxygen versus nitrogen).

Complexes 4 and 4' each gave a single sharp resonance in their ${ }^{7} \mathrm{Li}$ NMR spectrum at $0.78 / 0.79 \mathrm{ppm}$ respectively. These values lie downfield from Konishi and co-workers values for 2-picLi 40 although such values $(-0.05--0.62 \mathrm{ppm})$ were recorded in highly polar, oxygen containing solvents. ${ }^{21 \mathrm{~b}}{ }^{7} \mathrm{Li}-{ }^{1} \mathrm{H}$ HOESY experiments confirmed that the upfield shifted $=\mathrm{CH}_{2}$ resonance in $\mathbf{4}$ and 4' (at $2.83 / 2.79 \mathrm{ppm}$ respectively) represents the hydrogen atom cis to the ring nitrogen while the downfield resonance (at 3.46/3.44 ${ }_{45} \mathrm{ppm}$ respectively) represents the trans hydrogen atom since only the former ${ }^{1} \mathrm{H}$ resonance exhibited a ${ }^{7} \mathrm{Li}$ cross-peak in each case. NMR data for complex $\mathbf{6}$ (which may have a degree of aza-allylic bonding, vide supra) are similar to those of complexes 4, 4' and 5 and given the disparity between the NMR data of Stalke's two

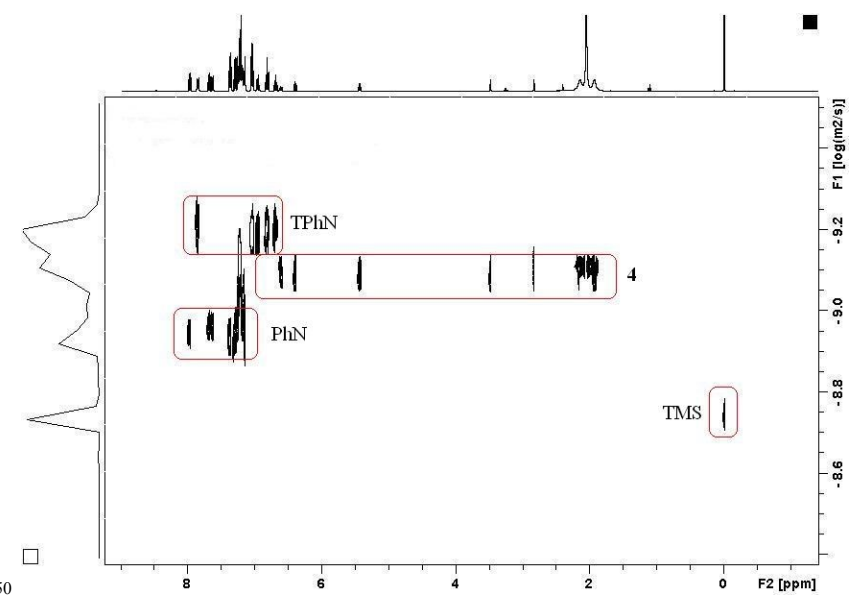

Figure $9{ }^{1} \mathrm{H}$ DOSY NMR spectrum of complex 4 in $\mathrm{C}_{6} \mathrm{D}_{6}$ solution at 300 $\mathrm{K}$ in the presence of inert standards 1,2,3,4-tetraphenylnaphthalene $(\mathrm{TPhN})$, 1-phenylnaphthalene $(\mathrm{PhN})$ and tetramethylsilane (TMS).

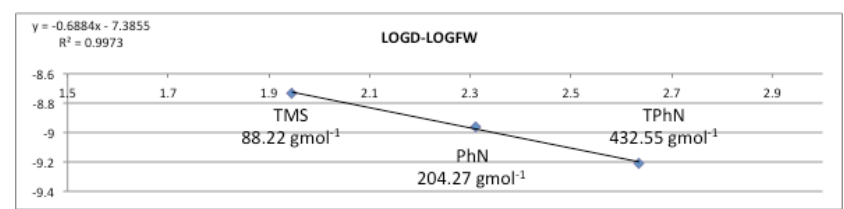

55 Graph 1 Plot of $\log \mathrm{D}$ versus $\log \mathrm{FW}$ from ${ }^{1} \mathrm{H}$ DOSY NMR data of the mixture of $\mathbf{4}$ and inert standards TPhN, $\mathrm{PhN}$ and TMS in $\mathrm{C}_{6} \mathrm{D}_{6}$ solution at $300 \mathrm{~K}$

Table 4 D-FW analysis from the ${ }^{1} \mathrm{H}$ DOSY NMR data of the mixture of 4 and standards TPhN, PhN and TMS in $\mathrm{C}_{6} \mathrm{D}_{6}$ solution at $300 \mathrm{~K}$

\begin{tabular}{|c|c|c|c|c|}
\hline Compound & $\mathrm{D}_{\mathrm{Av}}\left(\times 10^{-10} \mathrm{~m}^{2} \mathrm{~s}^{-1}\right)$ & $\log \mathrm{D}_{\mathrm{Av}}$ & $\mathrm{FW}\left(\mathrm{gmol}^{-1}\right)$ & $\log \mathrm{FW}$ \\
\hline $\mathrm{TPhN}$ & 6.20 & -9.207795 & $432.55^{\mathrm{a}}$ & 2.636036 \\
\hline $\mathrm{PhN}$ & 10.92 & -8.961645 & $204.27^{\mathrm{a}}$ & 2.310204 \\
\hline $\mathrm{TMS}$ & 18.55 & -8.731656 & $88.22^{\mathrm{a}}$ & 1.945567 \\
\hline $\mathbf{4}$ & 7.81 & -9.107571 & $317.36^{\mathrm{b}}$ & 2.501556 \\
\hline
\end{tabular}

${ }_{60}{ }^{\text {a }}$ Theoretical $\mathrm{FW}^{\mathrm{b}} \mathrm{FW}$ calculated from $[\log \mathrm{D}=-0.6884 \cdot \log \mathrm{FW}-7.3855$ $\left.\left(\mathrm{r}^{2}=0.9973\right)\right]$

aza-allyl complexes (table 4) it would be unwise to unequivocally assign such data to an enamido or aza-allyl structure in solution. Taking the NMR data of the newly prepared complexes together, ${ }_{65}$ it is clear that they all display similar ${ }^{1} \mathrm{H}$ NMR spectra, with each type of resonance appearing in a fairly narrow range indicative of a common (or at the very least similar) bonding motif.

\section{Experimental}

\section{General experimental}

70 All reactions and manipulations were performed under a protective argon atmosphere using either standard Schlenk techniques or a glove box. Hexane, THF and diethyl ether were dried by heating to reflux over sodium benzophenone ketyl and then distilled under nitrogen prior to use. PMDETA was distilled 75 over $\mathrm{CaH}_{2}$ and stored over $4 \AA \AA$ molecular sieves. 2-picoline and 4picoline were stored over $4 \AA$ molecular sieves. $n \mathrm{BuLi}(1.6 \mathrm{M}$ in hexanes) and $\mathrm{MO} t \mathrm{Bu}$ were purchased commercially from SigmaAldrich and used as received. Me 6 TREN was prepared by a literature method. ${ }^{22}$ NMR spectra were recorded on a Bruker AV ${ }_{80} 400 \mathrm{MHz}$ spectrometer operating at $400.13 \mathrm{MHz}$ for ${ }^{1} \mathrm{H}, 155.47$ $\mathrm{MHz}$ for ${ }^{7} \mathrm{Li}$ and $100.62 \mathrm{MHz}$ for ${ }^{13} \mathrm{C}$. All ${ }^{13} \mathrm{C}$ spectra were proton decoupled. Satisfactory elemental analyses of the air sensitive 
products could not be obtained so ${ }^{1} \mathrm{H}$ NMR spectra for all products except 2, which was not sufficiently soluble, are included in Supporting Information as evidence of good bulk purity.

\section{DOSY NMR Spectroscopy}

Diffusion-Ordered Spectroscopy (DOSY) NMR experiments were performed on a Bruker AVANCE 400 NMR spectrometer operating at $400.13 \mathrm{MHz}$ for proton resonance under TopSpin (version 2.0, Bruker Biospin, Karslruhe) and equipped with a 10 BBFO-z-atm probe with actively shielded z-gradient coil capable of delivering a maximum gradient strength of $54 \mathrm{Gcm}^{-1}$. Diffusion-ordered NMR data were acquired using the Bruker pulse program dstegp3s employing a double stimulated echo with three spoiling gradients. Sine-shaped gradient pulses were used 15 with a duration of $4 \mathrm{~ms}$ together with a diffusion period of 100 ms. Gradient recovery delays of $200 \mu$ s followed the application of each gradient pulse. Data were systematically accumulated by linearly varying the diffusion encoding gradients over a range of $2 \%$ to $95 \%$ of maximum for 64 gradient increment values. The 20 signal decay dimension on the pseudo-2D data was generated by Fourier transformation of the time-domain data. DOSY plots were generated by use of the DOSY processing module of TopSpin. Parameters were optimized empirically to find the best quality of data for presentation purposes. Diffusion coefficients 25 were calculated by fitting intensity data to the Stejskal-Tanner expression.

Samples were prepared by adding the desired complex $(0.1$ mmol) to an NMR tube containing 1,2,3,4tetraphenylnaphthalene (TPhN, $15 \mathrm{mg}), 1$-phenylnaphthalene $30(\mathrm{PhN}, 13.2 \mu \mathrm{L})$ and tetramethylsilane (TMS, 19.1 $\mu \mathrm{L})$ as inert internal reference standards. The ${ }^{1} \mathrm{H}$ DOSY NMR data were recorded at $300 \mathrm{~K}$. From the diffusion coefficients of the internal standards, linear calibration graphs were obtained by plotting $\log \mathrm{D}$ versus $\log \mathrm{FW}$. Using the diffusion coefficients for the 35 signals corresponding to the species under study an estimate of FW in solution was obtained.

\section{X-ray crystallography}

Crystallographic data were collected on Oxford Diffraction instruments with $\mathrm{Mo}$ or $\mathrm{Cu} \mathrm{K \alpha}$ radiation $(\lambda=0.71073$ and $401.54180 \AA$ respectively). Structures were solved using SHELXS$97,{ }^{23}$ while refinement was carried out on $F^{2}$ against all independent reflections by the full-matrix least-squares method using the SHELXL-97 program. ${ }^{23}$ All non-hydrogen atoms were refined using anisotropic thermal parameters. Selected 45 crystallographic details and refinement details are given in table 5. CCDC-991853 to CCDC-991858 contain the supplementary crystallographic data for this paper. These can be obtained free of charge from the Cambridge Crystallographic Data Centre via www.ccdc.cam.ac.uk/data request/cif.

\section{${ }_{50}$ General synthesis of picolyl-sodium and picolyl potassium salts}

$\mathrm{MO} t \mathrm{Bu}(16 \mathrm{mmol} ; \mathrm{M}=\mathrm{Na}, \mathrm{K})$ was dispersed in hexane $(10 \mathrm{~mL})$ with stirring. This suspension was cooled to $0^{\circ} \mathrm{C}$ then picoline $(1.6 \mathrm{~mL}, 16 \mathrm{mmol})$ was added followed by $n \mathrm{BuLi}(10 \mathrm{~mL}, 1.6 \mathrm{M}$ 55 in hexane, $16 \mathrm{mmol}$ ) slowly via syringe. An orange/brown solid precipitate formed which was collected by filtration, washed with hexane $(3 \times 10 \mathrm{~mL})$ and dried in vacuo to give the final product.

\section{Synthesis of 4-picLi•Me ${ }_{6}$ TREN (1)}

${ }_{60}$ 4-picoline (0.16 mL, $\left.1.6 \mathrm{mmol}\right), \mathrm{Me}_{6} \mathrm{TREN}(0.42 \mathrm{~mL}, 1.6 \mathrm{mmol})$ and hexane $(5 \mathrm{~mL})$ were added to a Schlenk flask and cooled to $0^{\circ} \mathrm{C}$. $n \mathrm{BuLi}(1 \mathrm{~mL}, 1.6 \mathrm{mmol})$ was slowly added precipitating an orange solid. THF $(\sim 3 \mathrm{~mL})$ was slowly added until a homogeneous solution was obtained. This solution was ${ }_{65}$ cooled to $-30^{\circ} \mathrm{C}$ where a crop of red crystals (153 mg, $29 \%$ ) was obtained.

${ }^{1} \mathrm{H}$ NMR (400.1 MHz, d8-THF, $\left.300 \mathrm{~K}\right): \delta 6.34\left(2 \mathrm{H}, \mathrm{d},{ }^{3} \mathrm{~J}_{\mathrm{H}-\mathrm{H}}=\right.$ $6.83 \mathrm{~Hz}$, picolyl $), 5.23\left(2 \mathrm{H}, \mathrm{d},{ }^{3} J_{\mathrm{H}-\mathrm{H}}=7.04 \mathrm{~Hz}\right.$, picolyl $), 2.68(2 \mathrm{H}$, $\left.\mathrm{s}, \mathrm{CH}_{2}\right), 2.58\left(6 \mathrm{H}, \mathrm{t},{ }^{3} \mathrm{~J}_{\mathrm{H}-\mathrm{H}}=6.50 \mathrm{~Hz}, 3 \mathrm{x} \mathrm{CH} 2\right), 2.35\left(6 \mathrm{H}, \mathrm{t},{ }^{3} \mathrm{~J}_{\mathrm{H}-\mathrm{H}}\right.$ $\left.70=6.63 \mathrm{~Hz}, 3 \times \mathrm{CH}_{2}\right) 2.18 \mathrm{ppm}\left(18 \mathrm{H}, \mathrm{s}, \mathrm{CH}_{3}\right)$.

${ }^{13} \mathrm{C}$ NMR (100.6 MHz, $\left.\mathrm{C}_{6} \mathrm{D}_{6}, 300 \mathrm{~K}\right): \delta 147.6$ (picolyl ipso), 143.7 (picolyl CH), 109.6 (picolyl $\mathrm{CH}), 58.9$ (3 x CH 2$), 53.8$ (3 x $\left.\mathrm{CH}_{2}\right), 46.2\left(\mathrm{CH}_{3}\right), 30.6 \mathrm{ppm}$ (picolyl $\left.\mathrm{CH}_{2}\right)$.

${ }^{7} \mathrm{Li}$ NMR (x): $\delta 0.38 \mathrm{ppm}$.

75

\section{Synthesis of 4-picNa•Me6TREN (2)}

Freshly prepared 4-picNa $(0.115 \mathrm{~g}, 1.0 \mathrm{mmol})$ was suspended in hexane $(5 \mathrm{~mL})$ with stirring and $\mathrm{Me}_{6}$ TREN $(0.26 \mathrm{~mL}, 1.0 \mathrm{mmol})$ was introduced. THF $(\sim 2 \mathrm{~mL})$ was slowly added until a 80 homogeneous solution was obtained. This solution was cooled to $-30^{\circ} \mathrm{C}$ where a crop of red crystals (92 mg, $28 \%$ ) was obtained.

${ }^{1} \mathrm{H}$ NMR $(400.1 \mathrm{MHz}, \mathrm{d} 8-\mathrm{THF}, 300 \mathrm{~K}): \delta 6.39\left(2 \mathrm{H}, \mathrm{d},{ }^{3} J_{\mathrm{H}-\mathrm{H}}=\right.$ $5.63 \mathrm{~Hz}$, picolyl $), 5.23\left(2 \mathrm{H}, \mathrm{d},{ }^{3} \mathrm{~J}_{\mathrm{H}-\mathrm{H}}=5.81 \mathrm{~Hz}\right.$, picolyl $), 2.60(2 \mathrm{H}$, $\left.{ }_{85} \mathrm{~s}, \mathrm{CH}_{2}\right), 2.53\left(6 \mathrm{H}, \mathrm{t},{ }^{3} \mathrm{~J}_{\mathrm{H}-\mathrm{H}}=6.69 \mathrm{~Hz}, 3 \times \mathrm{CH}_{2}\right), 2.32\left(6 \mathrm{H}, \mathrm{t},{ }^{3} J_{\mathrm{H}-\mathrm{H}}\right.$ $\left.=6.69 \mathrm{~Hz}, 3 \times \mathrm{CH}_{2}\right) 2.17 \mathrm{ppm}\left(18 \mathrm{H}, \mathrm{s}, \mathrm{CH}_{3}\right)$.

${ }^{13} \mathrm{C}$ NMR (100.6 MHz, $\left.\mathrm{C}_{6} \mathrm{D}_{6}, 300 \mathrm{~K}\right): \delta 145.0$ (picolyl $\mathrm{CH}$ ), 109.7 (picolyl $\mathrm{CH}$ ), 58.9 ( $3 \mathrm{x} \mathrm{CH}_{2}$ ), 53.8 (3 x CH 2$), 46.1 \mathrm{ppm}$ $\left(\mathrm{CH}_{3}\right)$. Picolyl ipso and $\mathrm{CH}_{2}$ carbon resonances were not 90 resolved.

\section{Synthesis of $[4-p i c K \cdot 2(4-p i c H)]_{\infty}$ (3)}

Freshly prepared 4-picK $(0.131 \mathrm{~g}, 1.0 \mathrm{mmol})$ was suspended in hexane $(5 \mathrm{~mL})$ with stirring and 4-picoline $(\sim 2 \mathrm{~mL})$ was slowly 95 added until a homogeneous solution was obtained. This solution was cooled to $-30^{\circ} \mathrm{C}$ where a crop of red crystals (47 mg, $15 \%$ ) was obtained.

${ }^{1} \mathrm{H}$ NMR (400.1 MHz, d8 $\left.-\mathrm{THF}, 300 \mathrm{~K}\right): \delta 8 \square 37 \square \square 4 \mathrm{H}, \mathrm{d},{ }^{3} J_{\mathrm{H}-\mathrm{H}}=$ $6.09 \mathrm{~Hz}$, picoline), $7.08 \square 4 \mathrm{H}, \mathrm{d},{ }^{3} J_{\mathrm{H}-\mathrm{H}}=5.19 \mathrm{~Hz}$, picoline), 6.56 $100\left(2 \mathrm{H}, \mathrm{d},{ }^{3} J_{\mathrm{H}-\mathrm{H}}=5.87 \mathrm{~Hz}\right.$, picolyl $), 5.32\left(2 \mathrm{H}, \mathrm{d},{ }^{3} J_{\mathrm{H}-\mathrm{H}}=6.32 \mathrm{~Hz}\right.$, picolyl), $2.65\left(2 \mathrm{H}, \mathrm{s}\right.$, picolyl $\left.\mathrm{CH}_{2}\right), 2.30 \mathrm{ppm}(6 \mathrm{H}, \mathrm{s}$, picoline $\left.\mathrm{CH}_{3}\right)$.

${ }^{13} \mathrm{C}$ NMR (100.6 MHz, C6 $\mathrm{D}_{6}, 300 \mathrm{~K}$ ): $\delta 150.5$ (picoline $\mathrm{CH}$ ), 148.1 (picolyl ipso), 147.2 (picoline ipso), 145.9 (picolyl $\mathrm{CH}$ ), 105125.1 (picoline $\mathrm{CH}$ ), 109.3 (picolyl $\mathrm{CH}$ ), 30.6 (picolyl $\mathrm{CH}_{2}$ ), 20.8 ppm (picoline $\mathrm{CH}_{3}$ ).

\section{Synthesis of 2-picLi•Me6TREN (4)}

2-picoline (0.16 mL, $1.6 \mathrm{mmol}), \mathrm{Me}_{6}$ TREN (0.42 mL, $\left.1.6 \mathrm{mmol}\right)$ 110 and diethyl ether $(10 \mathrm{~mL})$ were added to a Schlenk flask and cooled to $0^{\circ} \mathrm{C}$. $n \mathrm{BuLi}(1 \mathrm{~mL}, 1.6 \mathrm{mmol})$ was slowly added precipitating a dark solid. THF $(\sim 2 \mathrm{~mL})$ was slowly added until a homogeneous solution was obtained. This solution was cooled to $-30^{\circ} \mathrm{C}$ where a crop of purple crystals $(273 \mathrm{mg}, 52$ 
Table 5 Crystallographic data and refinement details for compounds 1-6

\begin{tabular}{|c|c|c|c|c|c|c|}
\hline & 1 & 2 & 3 & 4 & 5 & 6 \\
\hline Empirical formula & $\mathrm{C}_{22} \mathrm{H}_{44} \mathrm{LiN}_{5} \mathrm{O}$ & $\mathrm{C}_{22} \mathrm{H}_{44} \mathrm{~N}_{5} \mathrm{NaO}$ & $\mathrm{C}_{18} \mathrm{H}_{20} \mathrm{KN}_{3}$ & $\mathrm{C}_{15} \mathrm{H}_{29} \mathrm{LiN}_{4}$ & $\mathrm{C}_{18} \mathrm{H}_{36} \mathrm{~N}_{5} \mathrm{Na}$ & $\mathrm{C}_{15} \mathrm{H}_{29} \mathrm{KN}_{4}$ \\
\hline Mol. mass & 401.56 & 417.61 & 317.47 & 272.36 & 345.51 & 304.52 \\
\hline Crystal system & orthorhombic & orthorhombic & orthorhombic & triclinic & monoclinic & triclinic \\
\hline Space group & P $22_{1} 2_{1}$ & P $2{ }_{1} 2_{1} 2_{1}$ & Pna $2_{1}$ & P-1 & $\mathrm{P} 2{ }_{1} / \mathrm{n}$ & P-1 \\
\hline$a / \AA$ & $9.3900(3)$ & $9.2483(7)$ & $7.24604(12)$ & $9.2329(16)$ & $8.6737(4)$ & $9.1770(6)$ \\
\hline$b / \AA$ & $14.7150(4)$ & $15.1708(12)$ & $12.9546(2)$ & $13.071(3)$ & $15.2476(10)$ & $10.2187(8)$ \\
\hline$c / \AA$ & $18.0296(4)$ & $18.4204(15)$ & $17.9978(3)$ & $14.754(2)$ & $16.1518(12)$ & $10.7465(7)$ \\
\hline$\alpha /^{\circ}$ & 90 & 90 & 90 & $105.504(16)$ & 90 & $107.162(7)$ \\
\hline$\beta /^{\circ}$ & 90 & 90 & 90 & $91.111(13)$ & $93.219(5)$ & $93.767(5)$ \\
\hline$\gamma^{\circ}$ & 90 & 90 & 90 & $96.930(17)$ & 90 & $105.164(7)$ \\
\hline$V / \AA^{3}$ & $2491.22(12)$ & $2584.5(4)$ & $1689.44(4)$ & $1700.7(5)$ & $2132.8(2)$ & $918.15(11)$ \\
\hline$Z$ & 4 & 4 & 4 & 4 & 4 & 2 \\
\hline$\lambda / \AA$ & 0.71073 & 0.71073 & 0.71073 & 1.54180 & 0.71073 & 0.71073 \\
\hline Measured reflections & 27324 & 8480 & 21032 & 10190 & 9420 & 6705 \\
\hline Unique reflections & 5856 & 4942 & 4133 & 6270 & 4098 & 3719 \\
\hline$R_{\text {int }}$ & 0.0409 & 0.0247 & 0.0324 & 0.0488 & 0.0369 & 0.0231 \\
\hline Observed rflns $[I>2 \sigma(I)]$ & 4706 & 3176 & 3774 & 3423 & 2328 & 3059 \\
\hline GooF & 1.073 & 1.026 & 1.044 & 1.028 & 1.010 & 1.058 \\
\hline$R$ [on $F$, obs rflns only] & 0.0588 & 0.0890 & 0.0316 & 0.0823 & 0.0615 & 0.0426 \\
\hline$\omega R$ [on $F^{2}$, all data $]$ & 0.1458 & 0.2798 & 0.0679 & 0.2749 & 0.1577 & 0.1001 \\
\hline Largest diff. peak/hole e $/ \AA^{-3}$ & $0.305 /-0.224$ & $0.697 /-0.357$ & $0.182 /-0.183$ & $0.400 /-0.218$ & $0.271 /-0.180$ & $0.376 /-0.221$ \\
\hline
\end{tabular}

$\%)$ was obtained.

${ }^{1} \mathrm{H}$ NMR (400.1 MHz, C6 6 6, $\left.300 \mathrm{~K}\right): \delta 7.16(1 \mathrm{H}, \mathrm{d}, \mathrm{H} 5$, masked by solvent but confirmed by ${ }^{1} \mathrm{H}_{-}{ }^{13} \mathrm{C}$ HSQC NMR), $6.59(1 \mathrm{H}, \mathrm{dt}$, $\left.{ }^{3} J_{\mathrm{H}-\mathrm{H}}=5.95 \mathrm{~Hz}, \mathrm{H} 3\right), 6.37\left(1 \mathrm{H}, \mathrm{dd},{ }^{3} J_{\mathrm{H}-\mathrm{H}}=9.00 \mathrm{~Hz}, \mathrm{H} 2\right), 5.42$ ${ }_{5}\left(1 \mathrm{H}, \mathrm{dt},{ }^{3} \mathrm{~J}_{\mathrm{H}-\mathrm{H}}=6.27 \mathrm{~Hz}, \mathrm{H} 4\right), 3.46(1 \mathrm{H}, \mathrm{s}, \mathrm{H} 6), 2.83(1 \mathrm{H}, \mathrm{s}, \mathrm{H} 6)$, $2.18\left(6 \mathrm{H}\right.$, br s, $\left.3 \times \mathrm{CH}_{2}\right), 2.06\left(18 \mathrm{H}, \mathrm{s}, \mathrm{CH}_{3}\right), 1.96 \mathrm{ppm}(6 \mathrm{H}, \mathrm{br} \mathrm{s}$, $\left.3 \times \mathrm{CH}_{2}\right)$.

${ }^{13} \mathrm{C}$ NMR (100.6 MHz, C6 6 6, $\left.300 \mathrm{~K}\right): \delta 162.5$ (C1), 148.4 (C5), 131.2 (C3), 115.9 (C2), 95.3 (C4), 61.3 (C6), 56.7 (3 x CH 2 ), $1051.2\left(3 \times \mathrm{CH}_{2}\right), 45.4 \mathrm{ppm}\left(\mathrm{CH}_{3}\right)$.

${ }^{7} \mathrm{Li} \mathrm{NMR}\left(155.46 \mathrm{MHz}, \mathrm{C}_{6} \mathrm{D}_{6}, 300 \mathrm{~K}\right): \delta 0.78 \mathrm{ppm}$.

\section{Synthesis of 2-picLi•PMDETA (4')}

2-picoline (0.16 mL, $1.6 \mathrm{mmol})$, PMDETA (0.34 mL, $1.6 \mathrm{mmol})$ 15 and diethyl ether $(10 \mathrm{~mL})$ were added to a Schlenk flask and cooled to $0^{\circ} \mathrm{C}$. $n \mathrm{BuLi}(1 \mathrm{~mL}, 1.6 \mathrm{mmol})$ was slowly added precipitating an orange solid. THF $(\sim 2.5 \mathrm{~mL})$ was slowly added until a homogeneous solution was obtained. This solution was cooled to $-30^{\circ} \mathrm{C}$ where a crop of red crystals (405 mg, $93 \%$ ) 20 was obtained.

${ }^{1} \mathrm{H}$ NMR (400.1 MHz, C6 6 , $\left.300 \mathrm{~K}\right): \delta 7.08\left(1 \mathrm{H}, \mathrm{d},{ }^{3} J_{\mathrm{H}-\mathrm{H}}=5.42\right.$ $\mathrm{Hz}, \mathrm{H} 5), 6.61\left(1 \mathrm{H}, \mathrm{dt},{ }^{3} J_{\mathrm{H}-\mathrm{H}}=6.16 \mathrm{~Hz}, \mathrm{H} 3\right), 6.36\left(1 \mathrm{H}, \mathrm{dd},{ }^{3} J_{\mathrm{H}-\mathrm{H}}=\right.$ $9.00 \mathrm{~Hz}, \mathrm{H} 2), 5.41\left(1 \mathrm{H}, \mathrm{dt},{ }^{3} J_{\mathrm{H}-\mathrm{H}}=6.29 \mathrm{~Hz}, \mathrm{H} 4\right), 3.44(1 \mathrm{H}, \mathrm{s}$, H6), 2.79 (1H, s, H6), $2.07\left(12 \mathrm{H}, \mathrm{s}, 4 \times \mathrm{CH}_{3}\right), 1.91\left(3 \mathrm{H}, \mathrm{s}, \mathrm{CH}_{3}\right)$, ${ }_{25} 1.72 \mathrm{ppm}\left(8 \mathrm{H}, \mathrm{s}, \mathrm{CH}_{2}\right)$.

${ }^{13} \mathrm{C}$ NMR (100.6 MHz, C6 $\left.\mathrm{D}_{6}, 300 \mathrm{~K}\right): \delta 162.5$ (C1), 148.3 (C5), 131.3 (C3), 115.7 (C2), 95.2 (C4), 60.6 (C6), 56.6 (2 x CH$)$, $53.2\left(2 \times \mathrm{CH}_{2}\right), 45.1\left(4 \times \mathrm{CH}_{3}\right), 44.3 \mathrm{ppm}\left(1 \times \mathrm{CH}_{3}\right)$.

${ }^{7} \mathrm{Li}$ NMR (155.46 MHz, C6 6 6, $\left.300 \mathrm{~K}\right): \delta 0.79 \mathrm{ppm}$.

\section{Synthesis of 2-picNa•Me6TREN (5)}

Freshly prepared 2-picNa $(0.115 \mathrm{~g}, 1.0 \mathrm{mmol})$ was suspended in diethyl ether $(5 \mathrm{~mL})$ with stirring and $\mathrm{Me}_{6}$ TREN $(0.26 \mathrm{~mL}, 1.0$ mmol) was added. THF $(\sim 3 \mathrm{~mL})$ was slowly added until a 35 homogeneous solution was obtained. This solution was cooled to $-30^{\circ} \mathrm{C}$ where a crop of red crystals (186 mg, $54 \%$ ) was obtained.

${ }^{1} \mathrm{H}$ NMR $\left(400.1 \mathrm{MHz}, \mathrm{C}_{6} \mathrm{D}_{6}, 300 \mathrm{~K}\right): \delta 7.40\left(1 \mathrm{H}, \mathrm{d},{ }^{3} J_{\mathrm{H}-\mathrm{H}}=5.12\right.$ $\mathrm{Hz}, \mathrm{H} 5), 6.69\left(1 \mathrm{H}, \mathrm{dt},{ }^{3} J_{\mathrm{H}-\mathrm{H}}=6.18 \mathrm{~Hz}, \mathrm{H} 3\right), 6.37\left(1 \mathrm{H}, \mathrm{dd},{ }^{3} J_{\mathrm{H}-\mathrm{H}}=\right.$ $\left.{ }_{40} 8.83 \mathrm{~Hz}, \mathrm{H} 2\right), 5.49\left(1 \mathrm{H}, \mathrm{dt},{ }^{3} \mathrm{~J}_{\mathrm{H}-\mathrm{H}}=5.83 \mathrm{~Hz}, \mathrm{H} 4\right), 3.28(1 \mathrm{H}, \mathrm{s}$, H6), 2.96 (1H, s, H6), $2.05\left(18 \mathrm{H}, \mathrm{s}, \mathrm{CH}_{3}\right), 1.84 \mathrm{ppm}(12 \mathrm{H}, \mathrm{s}$, $\mathrm{CH}_{2}$ ).

${ }^{13} \mathrm{C}$ NMR (100.6 MHz, C6 $\left.\mathrm{D}_{6}, 300 \mathrm{~K}\right): \delta 164.8$ (C1), 150.5 (C5), 131.8 (C3), 113.8 (C2), 95.5 (C4), 59.1 (C6), 57.4 (3 x $\mathrm{CH}_{2}$ ), ${ }_{45} 51.6\left(3 \times \mathrm{CH}_{2}\right), 45.4 \mathrm{ppm}\left(\mathrm{CH}_{3}\right)$.

\section{Synthesis of [2-picK•PMDETA $]_{2}$ (6')}

Freshly prepared 2-picK $(0.131 \mathrm{~g}, 1.0 \mathrm{mmol})$ was suspended in diethyl ether $(5 \mathrm{~mL})$ with stirring and PMDETA $(0.42 \mathrm{~mL}, 2.0$ $50 \mathrm{mmol}$ ) was slowly added giving a homogeneous solution. This solution was cooled to $-30^{\circ} \mathrm{C}$ where a crop of red crystals (138 mg, $45 \%$ ) was obtained.

${ }^{1} \mathrm{H}$ NMR $\left(400.1 \mathrm{MHz}, \mathrm{C}_{6} \mathrm{D}_{6}, 300 \mathrm{~K}\right): \delta 7.36\left(1 \mathrm{H}, \mathrm{d},{ }^{3} J_{\mathrm{H}-\mathrm{H}}=4.40\right.$ $\mathrm{Hz}, \mathrm{H} 5), 6.52\left(1 \mathrm{H}, \mathrm{dt},{ }^{3} J_{\mathrm{H}-\mathrm{H}}=6.69 \mathrm{~Hz}, \mathrm{H} 3\right), 6.14\left(1 \mathrm{H}, \mathrm{dd},{ }^{3} J_{\mathrm{H}-\mathrm{H}}=\right.$ $558.80 \mathrm{~Hz}, \mathrm{H} 2), 5.35(1 \mathrm{H}, \mathrm{dt}, 6.16 \mathrm{~Hz}, \mathrm{H} 4), 3.17(1 \mathrm{H}, \mathrm{s}, \mathrm{H} 6), 2.88$ $(1 \mathrm{H}, \mathrm{s}, \mathrm{H} 6), 2.16\left(3 \mathrm{H}, \mathrm{s}, \mathrm{CH}_{3}\right), 2.13(12 \mathrm{H}, \mathrm{s}, 4 \mathrm{x} \mathrm{CH}), 2.08 \mathrm{ppm}$ $\left(8 \mathrm{H}, \mathrm{s}, \mathrm{CH}_{2}\right)$.

${ }^{13} \mathrm{C}$ NMR (100.6 MHz, C6D6, $\left.300 \mathrm{~K}\right): \delta 162.7$ (C1), 149.6 (C5), 132.0 (C3), 114.5 (C2), 96.0 (C4), 59.4 (C6), 57.5 (2 x CH 2 ), $6055.9\left(2 \times \mathrm{CH}_{2}\right), 45.3\left(4 \mathrm{x} \mathrm{CH}_{3}\right), 41.7 \mathrm{ppm}\left(1 \mathrm{x} \mathrm{CH}_{3}\right)$.

\section{Acknowledgements}

We are grateful to the Royal Society of Edinburgh (BP Trust Fellowship to S.D.R.), the U.K. Engineering and Physical Sciences Research Council (award no. EP/K001183/1) and the ${ }_{65}$ Royal Society (Wolfson research merit award to R.E.M.).

\section{Conclusions}

We have prepared a series of 2- and 4-picolyl alkali-metal (Li, 
$\mathrm{Na}, \mathrm{K}$ ) complexes and characterized them in solution by NMR spectroscopy and in the solid state by X-ray crystallography. In the case of lithium and sodium, monomeric complexes of this ligand have been identified for the first time with the absence of 5 aggregation being due to the polydenticity and generous steric protection provided by either of the bulky neutral polyamine Lewis donors PMDETA or Me6TREN. This has allowed an unimpeded view of the primary metal-anion bonding interactions in the solid state which show that the anion preferentially binds in 10 a $\eta^{1}$ enamide fashion. With the larger metal potassium, complexes were obtained as either a picoline-solvated polymer (containing the 4-picolyl anion) or a PMDETA solvated dimer (containing the 2-picolyl anion) with an aza-allyl type metalanion bonding motif. The 4-picolyl series were surprisingly not 15 amenable to a complete solution state study in non-interacting solvent due to their reduced solubility, however, the 2-picolyl series were revealed to maintain their structural integrity in benzene solution via DOSY NMR spectroscopy and to likely maintain their solid state metal-anion bonding motifs in solution.

\section{${ }_{20}$ Notes and references}

${ }^{a}$ WestCHEM, Department of Pure and Applied Chemistry, University of Strathclyde, Glasgow, G1 1XL, UK. E-mail:

stuart.d.robertson@strath.ac.uk

$\dagger$ Electronic Supplementary Information (ESI) available: CIF files giving

25 crystallographic results, ${ }^{1} \mathrm{H}$ NMR spectra and DOSY NMR spectra, tables and graphs. See DOI: 10.1039/b000000x/

1. A. F. Pozharskii, A. Soldatenkov and A. R. Katritzky, Heterocycles in Life and Society: An Introduction to Heterocyclic Chemistry,

30 Biochemistry and Applications, 2nd edn., Wiley, Chichester, 2011.

2. in Metabolic Pathways of Agrochemicals, ed. T. Roberts, RSC, Cambridge, 1998, pp. 419-433.

3. P. Kiuru and J. Yli-Kauhaluoma, in Heterocycles in Natural Product Synthesis, eds. K. C. Majumdar and S. K. Chattopadhyay, Wiley, Weinheim, Germany, 2011, pp. 267-297.

4. (a) A. Macchioni, G. Ciancaleoni, C. Zuccaccia and D. Zuccaccia, Chem. Soc. Rev., 2008, 37, 479-489; (b) F. A. Abu-Shanab, B. J. Wakefield and M. H. Elnagdi, Adv. Heterocycl. Chem., 1997, 68, 181-221.

40 5. C. W. Muir, A. R. Kennedy, J. M. Redmond and A. J. B. Watson, Org. Biomol. Chem., 2013, 11, 3337-3340.

6. F. A. Davis, J. Y. Melamed and S. S. Sharik, J. Org. Chem., 2006, 71, 8761-8766.

7. (a) D. Colgan, R. I. Papasergio, C. L. Raston and A. H. White, J.

45 Chem. Soc., Chem. Commun., 1984, 1708-1710; (b) R. I. Papasergio, B. W. Skelton, P. Twiss, A. H. White and C. L. Raston, J. Chem. Soc., Dalton Trans., 1990, 1161-1172; (c) P. C. Andrews, D. R. Armstrong, C. L. Raston, B. A. Roberts, B. W. Skelton and A. H. White, J. Chem. Soc., Dalton Trans., 2001, 996-1006; (d) W.-P.

50 Leung, L.-H. Weng, R.-J. Wang and T. C. W. Mak, Organometallics, 1995, 14, 4832-4836; (e) C. Jones, C. H. L. Kennard, C. L. Raston and G. Smith, J. Organomet. Chem., 1990, 396, C39-C42; (f) X. Chen, L. Guan, M. S. Eisen, H. Li, H. Tong, L. Zhang and D. Liu, Eur. J. Inorg. Chem., 2009, 3488-3495.

55 8. H. Ott, U. Pieper, D. Leusser, U. Flierler, J. Henn and D. Stalke, Angew. Chem. Int. Ed., 2009, 48, 2978-2982.

9. J. S. Dhau and A. Singh, J. Organomet. Chem., 2014, 749, 109-114.

10. R. A. Abramovitch, R. T. Coutts and E. M. Smith, J. Org. Chem., 1972, 37, 3584-3587.

60 11. (a) M. G. Davidson, D. Garcia-Vivo, A. R. Kennedy, R. E. Mulvey and S. D. Robertson, Chem. Eur. J., 2011, 17, 364-3369; (b) D. R. Armstrong, M. G. Davidson, D. Garcia-Vivo, A. R. Kennedy, R. E. Mulvey and S. D. Robertson, Inorg. Chem., 2013, 52, 12023-12032; (c) Me6 6 TREN is also effective for the stabilization of s-block cations:
D. Robertson, Angew. Chem. Int. Ed., 2011, 50, 8375-8378; (d) L. M. Guard and N. Hazari, Organometallics, 2013, 32, 2787-2794.

12. T. Cadenbach, E. Hevia, A. R. Kennedy, R. E. Mulvey, J.-A. Pickrell and S. D. Robertson, Dalton Trans., 2012, 41, 10141-10144.

70 13. D. M. Cousins, M. G. Davidson, C. J. Frankis, D. Garcia-Vivo and M. F. Mahon, Dalton Trans., 2010, 39, 8278-8280.

14. (a) L. Lochmann, J. Pospišil and D. Lim, Tetrahedron Lett., 1966, 7, 257-262; (b) M. Schlosser, J. Organomet. Chem., 1967, 8, 9-16; (c) M. Schlosser, Pure Appl. Chem., 1988, 60, 1627-1634; (d) L. Lochmann, Eur. J. Inorg. Chem., 2000, 1115-1126.

15. (a) T. S. Mansour, T. C. Wong and E. M. Kaiser, J. Chem. Soc., Perkin Trans. II, 1985, 2045-2048; (b) D. R. Armstrong, R. E. Mulvey, D. Barr, R. Snaith and D. Reed, J. Organomet. Chem., 1988, 350, 191-205; (c) D. Barr, R. Snaith, R. E. Mulvey and D. Reed, 80 Polyhedron, 1988, 7, 665-668; (d) W. Clegg, L. Dunbar, L. Horsburgh and R. E. Mulvey, Angew. Chem. Int. Ed. Engl., 1996, 35, 753-755.

16. (a) H. Gilman and J. W. Morton, Org. Reactions, 1954, 8, 258-304; (b) R. D. Clark and A. Jahangir, Org. Reactions, 1995, 47, 1-314; (c)

85 J. Arnold, V. Knapp, J. A. R. Schmidt and A. Shafir, J. Chem. Soc., Dalton Trans., 2002, 3273-3274; (d) C. Schade, P. v. R. Schleyer, H. Dietrich and W. Mahdi, J. Am. Chem. Soc., 1986, 108; (e) D. Hoffmann, W. Bauer, F. Hampel, N. J. R. van Eikema Hommes, P. v. R. Schleyer, P. Otto, U. Pieper, D. Stalke, D. S. Wright and R. Snaith, J. Am. Chem. Soc., 1994, 116, 528-536; (f) W. Clegg, G. C. Forbes, A. R. Kennedy, R. E. Mulvey and S. T. Liddle, Chem. Commun., 2003, 406-407; (g) D. R. Armstrong, J. Garcia-Alvarez, D. V. Graham, G. W. Honeyman, E. Hevia, A. R. Kennedy and R. E. Mulvey, Chem. Eur. J., 2009, 15, 3800-3807.

95 17. (a) P. C. Andrews, P. J. Duggan, G. D. Fallon, T. D. McCarthy and A. C. Peatt, J. Chem. Soc., Dalton Trans., 2000, 1937-1940; (b) P. C. Andrews, P. J. Duggan, M. Maguire and P. J. Nichols, Chem. Commun., 2001, 53-54.

18. K. W. Henderson, A. E. Dorigo, Q.-Y. Liu and P. G. Williard, J. Am. Chem. Soc., 1997, 119, 11855-11863.

19. D. Barr, W. Clegg, R. E. Mulvey, R. Snaith and D. S. Wright, J. Chem. Soc., Chem. Commun., 1987, 716-718.

20. D. Li, I. Keresztes, R. Hopson and P. G. Williard, Acc. Chem. Res., 2009, 42, 270-280.

105 21. (a) K. Konishi and K. Takahashi, Bull. Chem. Soc. Jpn., 1977, 50, 2512-2516; (b) K. Konishi, A. Yoshino, M. Katoh, K. Takahashi, Y. Kawada, T. Sugawara and H. Iwamura, Bull. Chem. Soc. Jpn., 1981, 54, 3117-3121.

22. G. J. P. Britovsek, J. England and A. J. P. White, Inorg. Chem., 2005, 44, 8125-8134.

23. G. M. Sheldrick, Acta Crystallogr., 2007, A64, 112-122. 